OECDpublishing

SUSTAINING ICELAND'S

FISHERIES THROUGH

TRADEABLE QUOTAS

COUNTRY STUDY

OECD ENVIRONMENT POLICY PAPER

December 2017 n09 


\section{Sustaining Iceland's fisheries through tradeable quotas}

\section{COUNTRY STUDY}

OECD ENVIRONMENT POLICY PAPER NO. 9

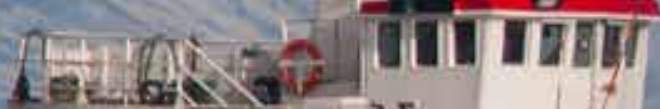

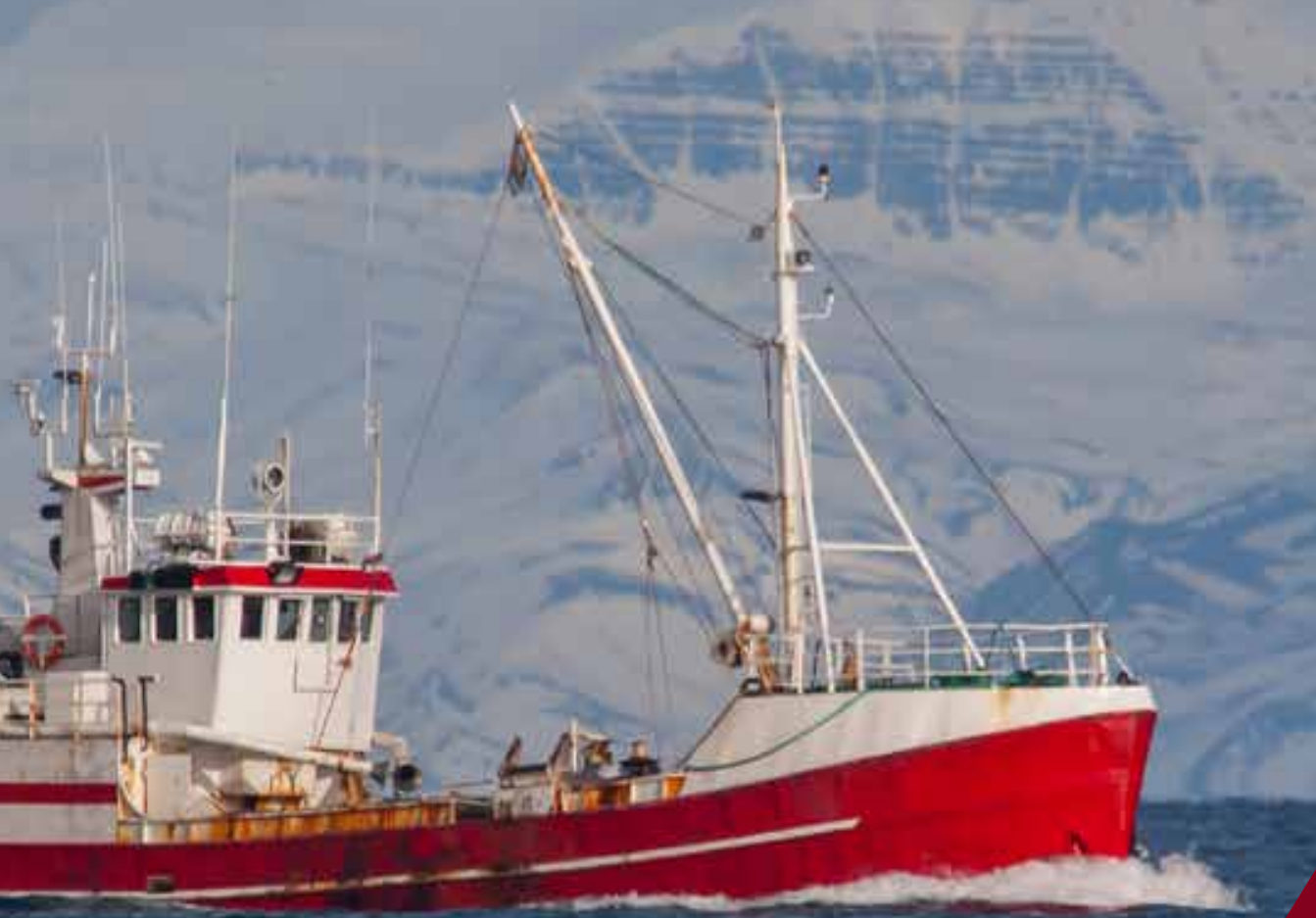

\section{(9)) OECD \\ BETTER POLICIES FOR BETTER LIVES}


This Policy Paper summarises key messages from the case study on the political economy of reform of the fisheries management system in Iceland. The detailed case study is available in the 2017 OECD report The Political Economy of Biodiversity Policy Reform. A separate "Policy Highlights" brochure, which distils key messages and lessons learned from the full report is also available.

\section{Disclaimers}

This paper is published under the responsibility of the Secretary-General of the OECD. The opinions expressed and the arguments employed herein do not necessarily reflect the official views of OECD member countries.

This document and any map included herein are without prejudice to the status of or sovereignty over any territory, to the delimitation of international frontiers and boundaries and to the name of any territory, city or area.

For Israel, change is measured between 1997-99 and 2009-11. The statistical data for Israel are supplied by and under the responsibility of the relevant Israeli authorities. The use of such data by the OECD is without prejudice to the status of the Golan Heights, East Jerusalem and Israeli settlements in the West Bank under the terms of international law.

\section{Copyright}

You can copy, download or print OECD content for your own use, and you can include excerpts from OECD publications, databases and multimedia products in your own documents, presentations, blogs, websites and teaching materials, provided that suitable acknowledgment of OECD as source and copyright owner is given. All requests for public or commercial use and translation rights should be submitted to rights@oecd.org. Requests for permission to photocopy portions of this material for public or commercial use shall be addressed directly to the Copyright Clearance Center (CCC) at info@copyright.com or the Centre français d'exploitation du droit de copie (CFC) at contact@cfcopies.com.

\section{(c) OECD 2017}

\section{ISSN 2309-7841}

Authorised for publication by Anthony Cox, Acting Director, Environment Directorate 

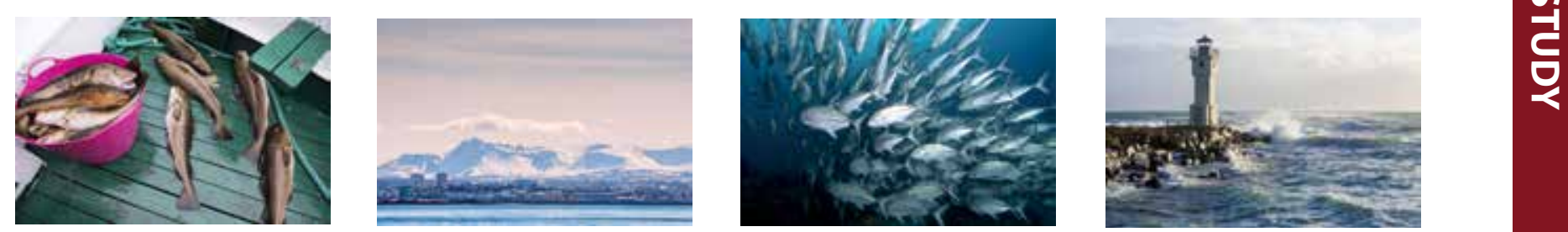

\section{Contents}

1. Overview

2. Sustaining Iceland's fisheries through tradeable user rights

3. The initial policy challenge: sustaining a common resource

4. Policy response

5. Economic, environmental and social impacts

6. Lessons learned

7. References 


\section{Overview}

Iceland's rich marine resources are vital to the country's prosperity, but prior to the 1990s were being depleted at an unsustainable rate. This was despite efforts to impose various restrictions on fishing and to keep out foreign fleets. Without further drastic action, fish stocks and the entire industry based upon them was in imminent danger of collapse, threatening major economic hardship for the entire country.

\section{The challenge}

As a common property resource, fisheries are notoriously difficult to manage in a sustainable manner. Imposing limits on fishing gear, effort and fishing periods was simply prompting a "race to fish" amongst competing vessels in Iceland's fishing industry. There was no incentive for individuals to hold back their fishing effort and the fishery continued to suffer from overexploitation. This situation was exacerbated by government support to the industry - including allowing total catch volumes which exceeded scientifically recommended levels.

\section{The policy response}

In the face of looming disaster and with little time for broad consultation, the government introduced a comprehensive system of individual transferable quotas (ITQs) via the Fisheries Act in 1990. The ITQ system gives fishers permanent quota shares which they can also lease or sell, providing an incentive to take a long-term view on the harvesting and management of the resource. Fishers can be confident of being able to reap the benefits later of restricting fishing now. Alternatively, less efficient vessels can opt to leave the industry and receive compensation through the sale of their quotas, thus helping to encourage a more efficient and profitable sector.

\section{The impact}

The Icelandic ITQ system is seen as a success in terms of economic efficiency and as a way of drastically reducing fishing effort to safeguard the sustainability of fish stocks. It provided the incentives for fishers to safeguard stocks through decreasing effort and catches, while at the same time securing their long-term economic future. Although conserving biodiversity was not an explicit objective, the reform created the necessary incentives to reduce total catch levels and thus to put the fishery on a sustainable footing. Currently, none of the commercially harvested species in Iceland is considered to be threatened due to overfishing.

\section{Key messages}

This major reform was able to be adopted quickly in the face of an urgent threat to an economically important industry. Limited stakeholder consultation allowed the reform to be enacted rapidly, but meant that subsequent piecemeal amendments were needed to respond to stakeholder demands. For example, while overall economic gains were positive, there were still winners and losers. Various changes have been made over time to address these concerns. These include the introduction of a resource rent tax in 2012 to allow the general public to share in the benefits of harvesting this commonly owned resource. 


\section{Sustaining Iceland's fisheries through tradeable user rights}

Fishing is a mainstay of the Icelandic economy. The warm and cold currents in Icelandic seas combined with nutrient-rich seawater provide an environment highly conducive to flourishing marine life and high-yield fishing grounds. This productive marine ecosystem has supported a robust fishing industry, accounting for about $5 \%$ of gross domestic product (GDP) in 2015, and is still vital to Iceland's prosperity, being the most important industry in many rural regions.

From the end of World War II, however, the increasingly unsustainable exploitation of fisheries became a serious problem. Fishing in Iceland expanded considerably in the post-war period, with fishing fleets taking ever-increasing catches due to technological advances and a considerable increase in the size of the Icelandic fleet. Contrary to the prevailing belief at the time, good fishery management was not secured by imposing various restrictions on fishing, limiting access by foreign fleets or providing subsidies for scrapping fishing vessels. In the 1970s and early 1980s, Iceland's Marine Resource Institute published alarming reports (known as "The Black Reports"), warning that if overfishing continued catches were going to fall drastically and calling for reform.

This paper describes the reform taken by Iceland to avert this looming crisis and restore fish stocks to sustainable levels. The paper outlines the process involved in designing and implementing this reform. It also reflects on the challenges encountered and the environmental, economic and social impacts of the reform. It concludes by discussing some wider lessons raised for other governments seeking to tackle similar environmental problems. 


\section{The initial policy challenge: sustaining a common resource}

Following the publication of the first Black Report in 1975, the government introduced several measures to manage the fishery. These were predominantly "effort restrictions" (limitations on the number of days spent at sea and on the type of gear used), as well as setting total allowable catches (TACs) for different species. To reduce fishing by vessels from other nations, fishing limits had gradually been extended, to 12 miles, 50 miles and 200 miles in 1958, 1972 and 1976 respectively, resulting in significant declines of foreign catches in Icelandic waters.

However, none of these efforts dealt with the common property nature of the resource, and the fishery continued to suffer from overexploitation. It became apparent that Icelanders themselves had increased their fishing fleets and effort beyond what was biologically sustainable and that the economic performance of the fishing industry was poor as a result. The emphasis had been on increasing investments - often with state support - in the fishing fleet to generate jobs and support rural regions depending on fisheries (Schrank, 2003; Matthiasson, 2008). Furthermore, political and economic pressure from both the electorate and the industry meant that decisions by the Minister of Fisheries on allowable catches most often exceeded the scientifically determined TAC advised by the Marine Resource Institute, resulting in higher actual landings (Figure 1). These deviations from the scientific recommendations were justified by referring to the uncertainty of scientific evidence and the economic and social necessity of safeguarding employment.

Figure 1. Fish catches regularly exceeded the recommended TAC for cod, 1995-2015 (metric tonnes)

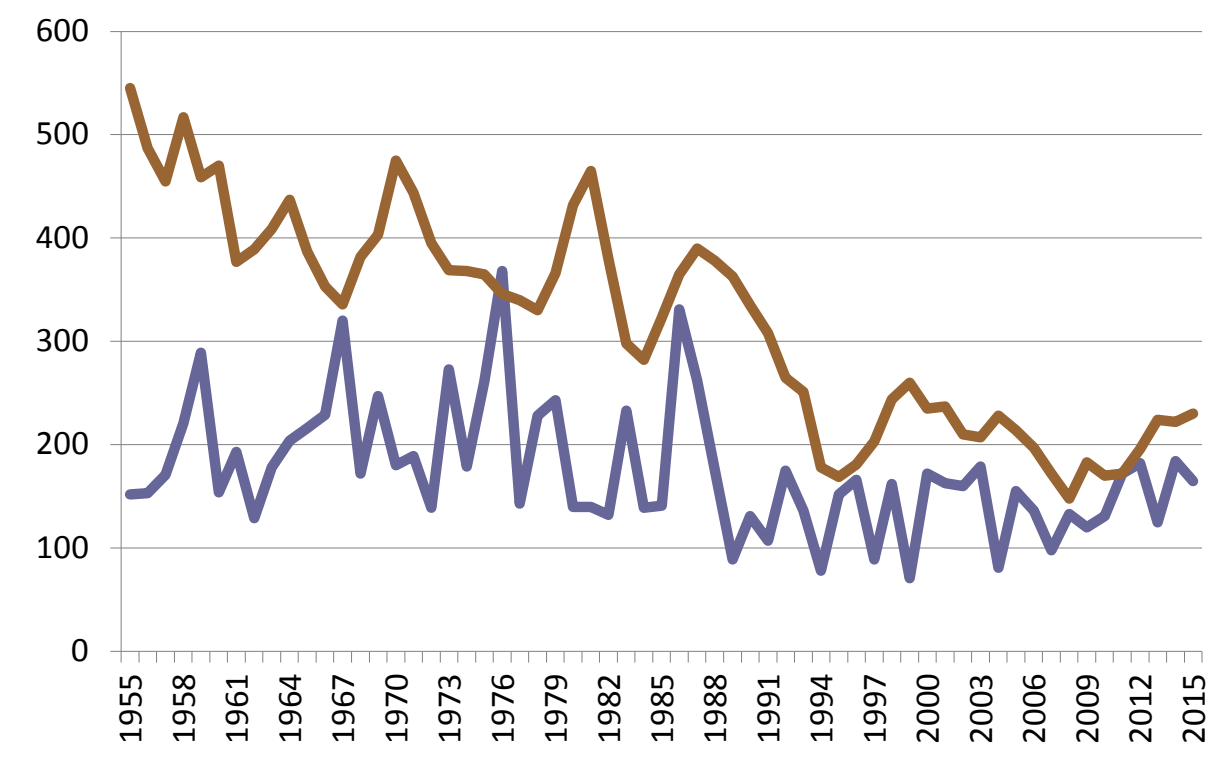

Source: Based on data from Marine Research Institute (2016), http://data.hafro.is.

A second Black Report was released in 1983. It was clear that the status quo would most likely lead to disaster. Given the importance of the fisheries for the national economy, its collapse would most certainly result in major economic hardships for the country as a whole. The poor economic performance of the fisheries, coupled with scientific evidence on the poor state of commercially important stocks, finally pushed parliament to introduce additional management measures. 


\section{Policy response}

A comprehensive system of individual transferrable quotas (ITQs) was introduced with the Fisheries Act in 1990. The reform built on ITQ systems that had been previously used in some fisheries (herring, capelin, and demersal fisheries ${ }^{1}$ ), and which had proven to be very successful in reducing fleet sizes and fishing effort. The essential feature of the ITQ system is that the quotas represent defined shares in the TAC of given stocks each fishing year (Box 1). While it was necessary to reduce TACs for many species, notably cod, the fishers received quota shares in return, which helped them to survive the consequent economic hardships. The quotas are permanent, perfectly divisible and fairly freely transferable. Discarding of fish is prohibited, as is high-grading (an attempt to increase the value of the catch by tossing out lowvalue fish caught unintentionally).

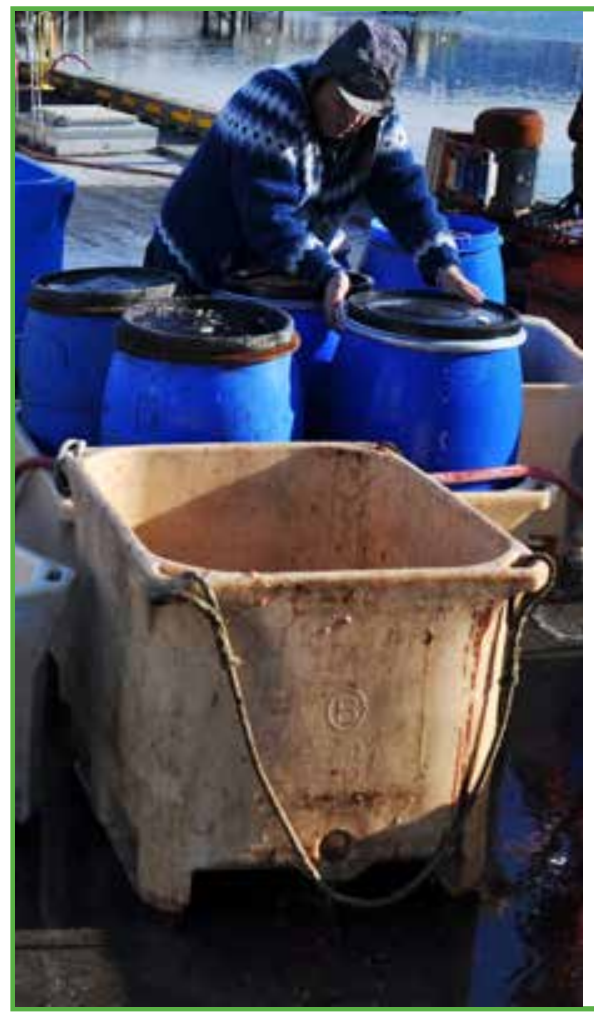

B ox 1. What a re ind i vidua I

transferrable quotas and why are they i m porta $\mathrm{nt}$ ?

Individual transferable quotas (ITQs) for fisheries are a property rights system that creates incentives for fishers to harvest fish stocks sustainably. ${ }^{2}$ The regulator sets a species-specific total allowable catch (TAC), then allocates portions of the TAC, called quotas, to individual fishers or fishing companies to be held in perpetuity. These quotas give fishers secure access to harvesting rights which enables them to take a long-term perspective on the sustainable management of the resource; they can be confident that by restricting fishing to within sustainable levels it will safeguard their harvest or increase their opportunities to increase fishing later. Restricting the TAC to sustainable levels also increases the value of quotas. This is of utmost importance as it eliminates the wasteful race-to-fish and the so-called "tragedy of the commons", in which many individual users acting in their own selfinterest deplete a shared resource through unregulated action. If the TAC is set at an appropriate level and there is effective monitoring and enforcement, ITQs can result in sustainable exploitation of fish stocks.

ITQ systems also create incentives for fishers to operate in an economically efficient manner. The quotas are transferrable, so owners can trade, lease or sell them. This creates financial incentives to maximise the net return they generate on their quota. The less efficient vessels can exit the fishery, for which they are compensated through the sale of their quotas.

The ITQ reform process was primarily driven by scientists, politicians and public servants. The involvement of other stakeholders, such as industry leaders and trade unions, was minimal. The limited initial stakeholder engagement allowed for the rapid adoption of this major reform, but it meant that piecemeal adjustments were later made to the system to respond to stakeholder demands. For example, regional quotas were put in place to support communities where fishing is an economic mainstay; small vessels were initially exempted from the ITQ system to protect rural employment; and a coastal fisheries system was devised to accommodate new entrants using small-scale line fishing, considered by some to be more ecologically sound. However, some of these exemptions and adjustments undermined the economic efficiency and sustainability of the fisheries management system (discussed below). 


\section{Economic, environmental and social impacts}

\section{Economic impacts}

From a pure economic theory point of view, property rights-based systems in fisheries, if designed and implemented correctly, should yield numerous economic benefits, including:

- Reduced fishing effort due to the elimination of competition between vessels.

- Reduced cost of effort as firms can focus on catching their share with the lowest costs.

- Improved quality of catch as the firms are restricted by the quotas and can only increase revenue by improving quality.

- Reduction in fleet size due to rationalisation through buying and selling of quotas (less efficient vessels sell quotas and opt out of the fishery).

- The generation of profits.

There is ample evidence to support the view that the Icelandic ITQ system has been very successful in increasing efficiency in the fisheries. Overcapitalisation, in the form of too large a fleet, unravelled quickly and profitability increased (Figure 2). The former situation in which the fishing fleet was receiving state aid rapidly became history. ${ }^{3}$ Although direct subsidies in the Icelandic fisheries were generally lower than in many other countries, various support programmes existed, e.g. public investments funds, funds granting fuel subsidies, vessel buyback programmes and export grants. Also, before the ITQ system, the exchange rate of the national currency was regularly adjusted to improve the competitiveness of Iceland's fish exports. ${ }^{4}$ These support measures all ceased after the introduction of the ITQs.

Following the ITQ reforms, total productivity in the fishing industry increased - it was 73\% higher in 1995 than in 1973, compared to an increase in total productivity in other industries (excluding fish processing) of 21\% over the same period (National Economic Institute, 1999). One measure of the economic efficiency of the ITQ system is quota values over time. The annual quota rental values in the Icelandic fisheries increased dramatically (around 20-fold) between 1984 and 1999 (OECD, n.d.).

3. For a discussion see e.g. Arnason (2005) and Asche et al. (2014). 4. For a discussion see Schrank (2003).

Figure 2. Significant consolidation of the Icelandic fishing fleet led to higher profitability

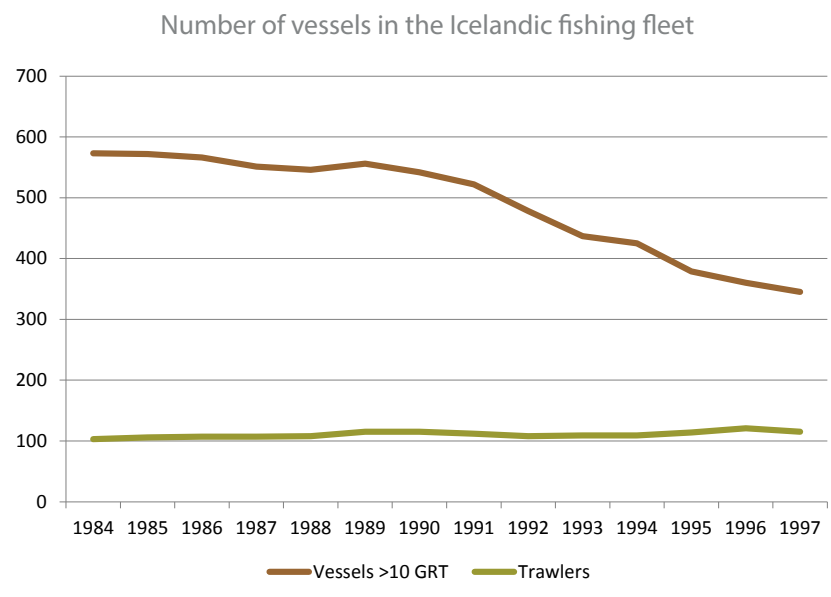

Note: GRT= "gross registered tonnes".

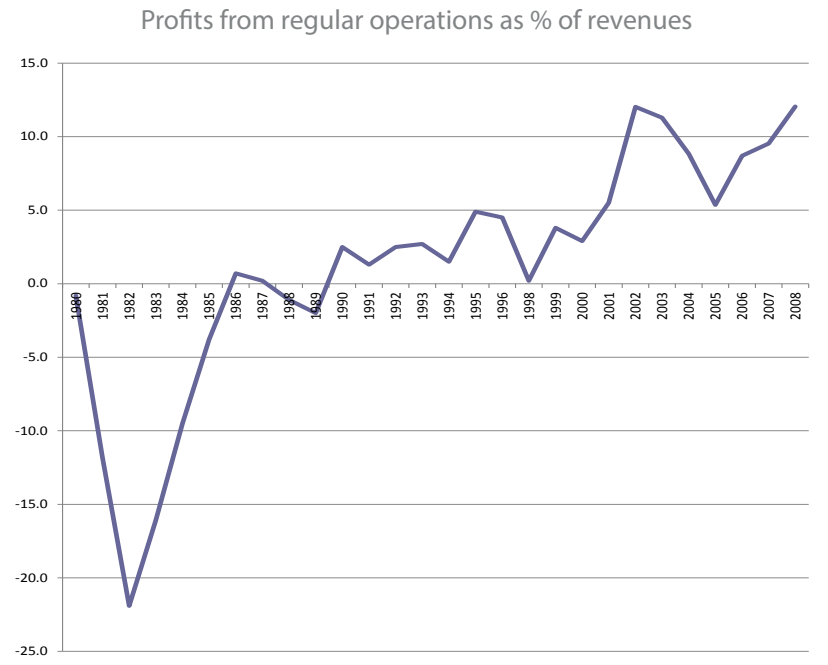

Source: Based on data from Statistics Iceland (2016), Rekstraryfirlit fiskveiða 1997-2015 [http://px.hagstofa.is/pxis/pxweb/is/Atvinnuvegir/ Atvinnuvegir_sjavarutvegur__afkomasja/SJA08101.px, (accessed 16 August 2016); and personal communication with G. Thordardottir. 

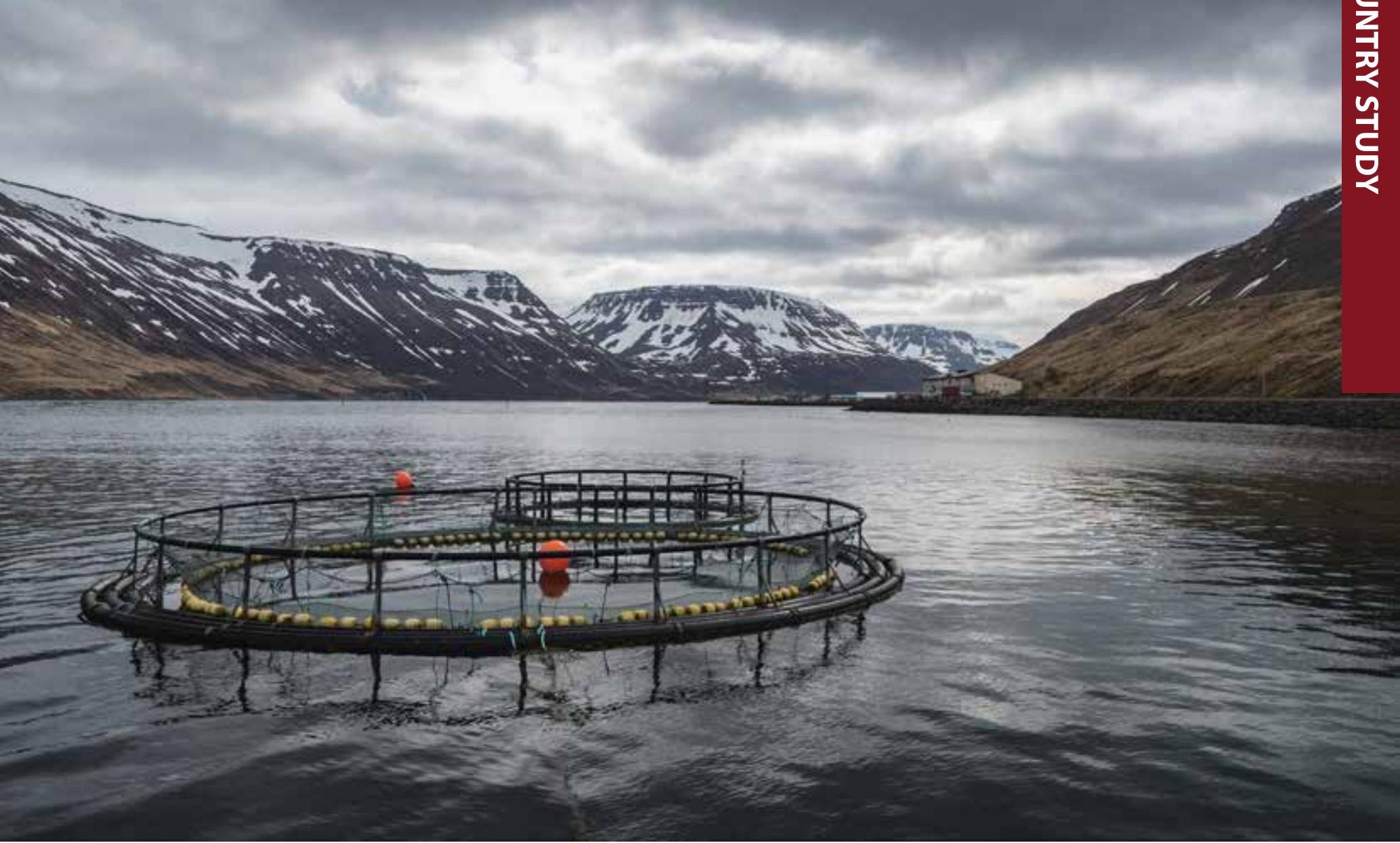

\section{Environmental impacts}

It is more difficult to evaluate the biological success of the system because of the inherent complexity and dynamics of the ecological system. However, it is clear that the reduction in fishing effort has secured the sustainability of most of the commercially exploited species. Figure 3 shows that since the ITQs were introduced, cod spawning has slowly begun to stabilise and recover from the sharp declines of previous decades. Currently, none of the commercially harvested species in Iceland is considered to be threatened due to overfishing. For many years, demersal fish catches exceeded levels recommended by scientists, but over the past decade the limit of total allowable catches has been in line with the advice of the Marine Research Institute (see Figure 1).

Figure 3. Trends in spawning stock biomass for cod

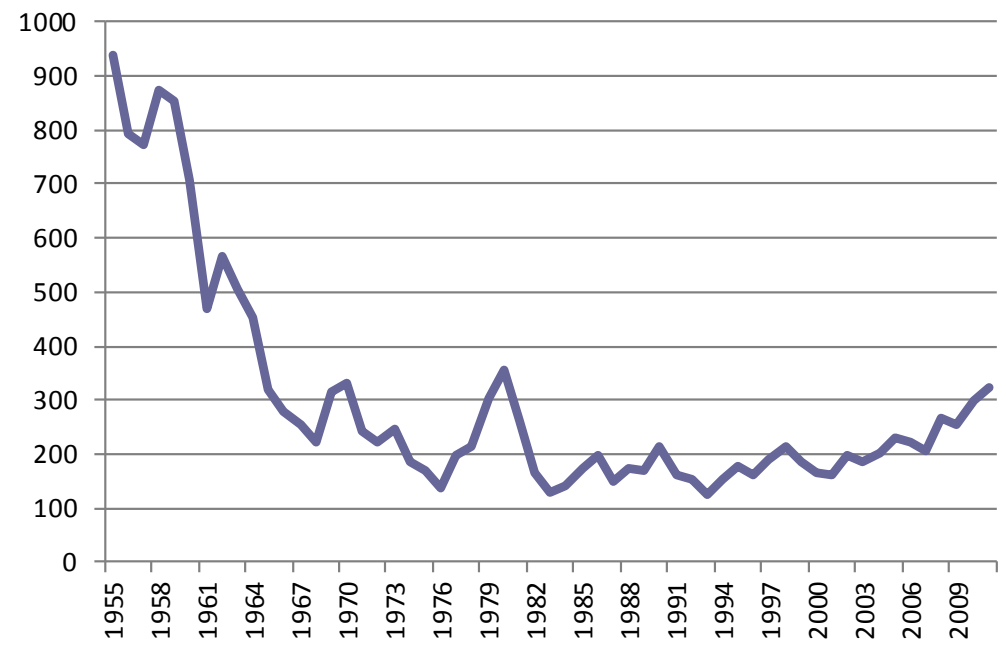

Source: Based on data from Marine Resource Institute (2016), http://data.hafro.is/assmt/2016/cod/. 


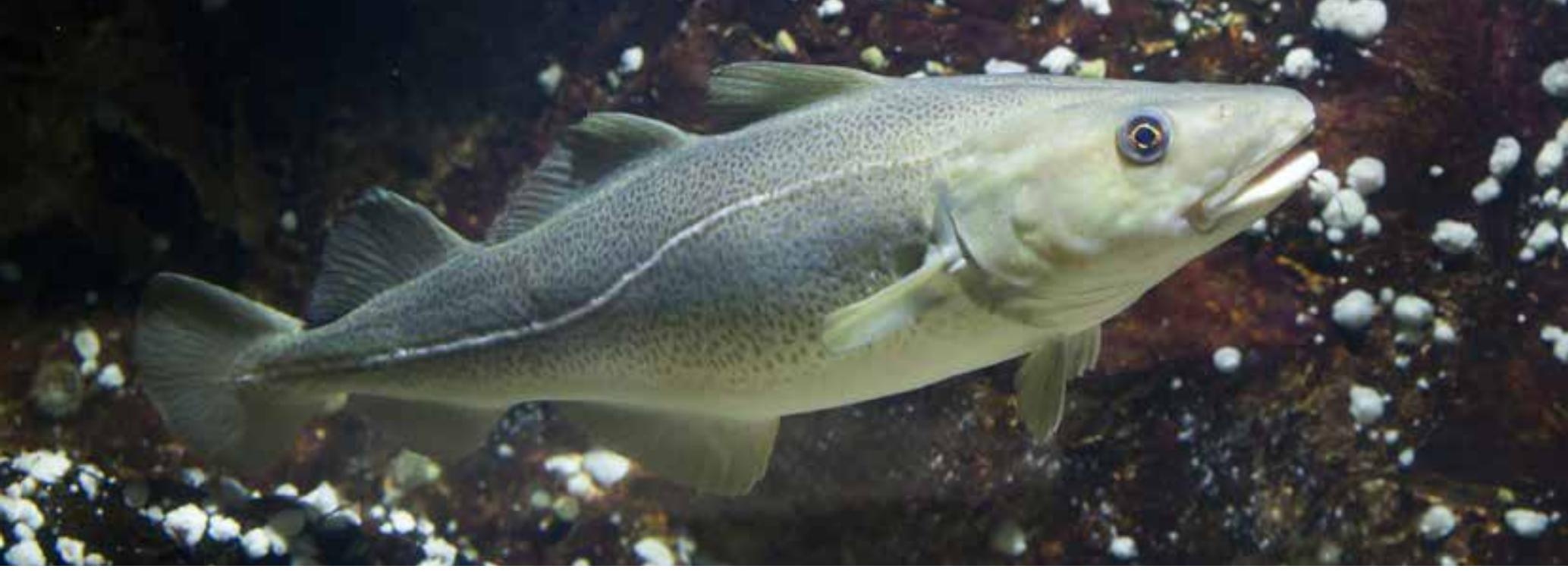

While the main purpose of most of the marine fisheries management areas (i.e. geographically designated management areas) has been to secure the sustainable use of the harvested resources, their goal was not necessarily to conserve biological diversity per se (MENR, 2014). For this reason, traditional management measures that protect habitat and reproduction capabilities in the ecosystem have always been applied along with the ITQ system in Iceland. These measures include closures of spawning grounds and areas to protect juveniles, as well as restrictions on gear types for certain time periods and fishing grounds. These measures are based on scientific recommendations provided by the Marine Research Institute and are implemented frequently. Some zones have been closed to fishing for many years, while others are closed for shorter time periods. The Coast Guard plays an active role in patrolling these management measures.

\section{Social impacts}

While the ITQ system has been considered a success from an economic efficiency perspective and has helped fish stocks to recover, political tensions and discontent have still come to the surface. The emergence of distinct winners and losers prompted political demands that have led to a number of exemptions and amendments to the system over the years, as well as efforts to better distribute the benefits of harvesting this commonly owned resource. Some of the key social questions facing policy makers, and how they were addressed, are outlined below.

\section{How to ensure fair sharing of benefits?}

Introducing a property rights-based system, such as ITQs, leads to changes that benefit some more than others. Much of the discontent over the years following the reform has been due to the initial free allocation of the quotas to existing fishers based on their catch levels at the time. This approach of initially "grandfathering" fishing rights is very common for property rights-based systems because it is often politically easiest and can be more efficient than some other means of distribution. However, more than three decades later, this is considered by some people in and outside the industry to have been an unjust way of allocating rights to harvest a commonly owned resource. According to the Fisheries Act, fish in Icelandic waters are the common property of the nation, yet the right to harvest them has been transferred to the quota owners. People who live in fishing regions where quotas are sold or leased are often left with few other employment opportunities and can experience economic and social hardships. Although the quota owners receive payment for their quotas, others that depended on fishing for their livelihood, directly or indirectly, do not receive such payments. While it is undeniable that the Icelandic economy has benefitted greatly from a more efficient fishing industry, the ITQ system generates profits for companies in the industry which some believe should be shared to a greater extent to the general public.

A resource rent tax introduced in 2012 sought to remedy some of these concerns. The tax takes into consideration the profit margin of harvesting different species and the revenues raised go to the general government budget. The tax levied on the industry amounted to ISK 12.8 billion for the fishing year 2012/13 and ISK 7.7 billion for the fishing year 2014/15 To put this into perspective, total tax receipts from all Icelandic firms (tax on revenue and profits) amounted to roughly ISK 58.6 billion in 2015 (Statistics Iceland, 2014; The Financial Management Authority, 2016).

\section{How to safeguard small-scale fishers?}

The transferability of quotas is an essential feature if a quota system is to increase the economic efficiency of the fishery. Quotas are sold or leased from less efficient vessels to more efficient ones. The smallest boats in the fishing fleet were originally exempt from the ITQ system due to political desire to conserve employment in rural fishing villages by safeguarding this fleet from 
consolidation through quota trade. However, although as a fleet they were allocated a total catch limit, no restrictions were put on effort or catches for individual boats. The catches of this fleet were substantial, accounting for around 35\% of the total cod catches in Iceland in the 1994/95 fishing year. After various attempts to reduce the fishing effort of these small vessels, the Minister of Fisheries finally decided in 2004 to require them to enter the ITQ system.

Demands were still made for specific measures for smaller vessels, however, mostly on the ground that entry into the fishing industry was difficult for newcomers. Also, small-scale hand-line fishing was considered by some to be ecologically superior to other fishing methods - and it was argued that encouraging such activities could create employment and revitalise fishing communities. The authorities thus allowed for a specific coastal fishery system, which opened up in 2009. This is mainly a cod-fishery where small vessel owners can apply for a specific license. The only gear allowed is hand-line and the fishing season is limited to the summer months. However, this rapidly has turned into a derby-style fishery, with fishers competing to catch as much as quickly as possible. As this fishing is mostly carried out by seasoned fishers who had already left the industry or are already quota holders, it failed to ease access for new entrants (University Centre of the Westfjords, 2010).

This experience clearly shows the complicated political economy issues that can arise in fisheries reforms where certain fleet segments are not treated in the same way. By exempting small-scale fishers from being managed under an ITQ system they had an incentive to free-ride instead of participating in rebuilding fish stocks (Haraldsson, 2008).

\section{How to protect fishing-dependent regions?}

There have also been concerns about quotas being sold or leased from towns or regions where fishing is the mainstay of the economy. To address these concerns, special regional quotas were introduced in 2002. The authorities set aside a part of the TAC for specific species and distributed it to rural regions. As ITQs are determined as a percentage of TACs, this meant that the regional quotas were distributed at the cost of quota holders, who were not compensated for their loss. These quotas are a relatively small share of the total TAC and decisions regarding their distribution are taken by the Minister of Fisheries. These decisions are based on various factors, such as the employment status of the town or region concerned, whether quotas have been leased or sold from the area, how dependent the region is upon fisheries, etc. The idea behind the regional quotas is to help the communities rather than the fishing firms directly.

Whether and how the ITQ system has affected regional development in Iceland is a complicated issue as factors other than fisheries have an effect on whether people and businesses leave or enter various regions. ${ }^{5}$ A recent study indicates that the effects of the regional quotas differ widely from one region to another (Karlsson and Johannesson, 2016). Interestingly, the regional quota allocation has also benefitted the greater capital region, due to its geographical proximity to some of the regions that received regional quotas. This is probably due to the region's importance in processing and handling fish (Karlsson and Johannesson, 2016).

5. See Runolfsson (1997) and Ásgeirsson (2012).

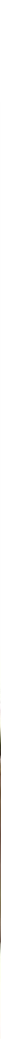




\section{Lessons learned}

The Icelandic ITQ system has been a success in terms of economic efficiency and as a way of drastically reducing fishing effort to safeguard the sustainability of the fish stocks. It provided the correct incentives for the sustainable harvesting of fish and made it possible for fishers to safeguard stocks through decreasing effort and catches, while at the same time securing their long-term economic future.

However, the reform still generated winners and losers, an issue which piecemeal amendments following the reform have sought to address. Understanding the political economy of reform - i.e. how decisions are made, in whose interests and how reform is promoted or obstructed and why - can be crucial to reform success. This is certainly the case for biodiversity related reform, where obstacles can include competitiveness concerns, distributional implications (impacts on income), vested interests, and political feasibility (OECD, 2017). What lessons with wider resonance have emerged from the Icelandic experience?

\section{An imminent crisis aided speedy adoption}

The introduction of the Icelandic ITQ system for managing its fisheries was a major reform spurred by an imminent collapse of the most important fish stock, which would have put the fishing industry in peril and would have meant economic hardship for the country as a whole. Given the importance of the fishing activity to the Icelandic economy people were willing to undertake strong measures. Having positive experiences from similar measures on a smaller scale helped.

\section{Limited initial stakeholder engagement led to subsequent piecemeal reforms}

Generally, stakeholder engagement can help secure the broad support and durability of reforms. Where governments need to act quickly to avert a crisis, however, a balance needs to be struck to provide opportunities for stakeholder engagement, without unduly delaying the reform process. In the case of Iceland, some industry stakeholders, such as fishers and people whose livelihood depended to a great extent on fishing, were not explicitly engaged in the reforms or the implementation of the ITQ system. Including every possible stakeholder group would have taken time and resulted in a political debate at every step of the process. On the other hand, limited initial stakeholder engagement meant that subsequent piecemeal amendments were later made - such as to protect small fishers and certain regions - which may have undermined the sustainability and efficiency of the system. Such trade-offs are typical of the political economy surrounding biodiversity related reforms.

\section{Overall economic gains may be positive, but there are still winners and losers}

Although the ITQ system increased the economic efficiency and profitability of fisheries, the initial free allocation of quotas via the grandfathering scheme raised concerns about the distribution of benefits reaped from a common property resource. The resource rent tax offered a constructive way of allowing the country to share the benefits more widely. 

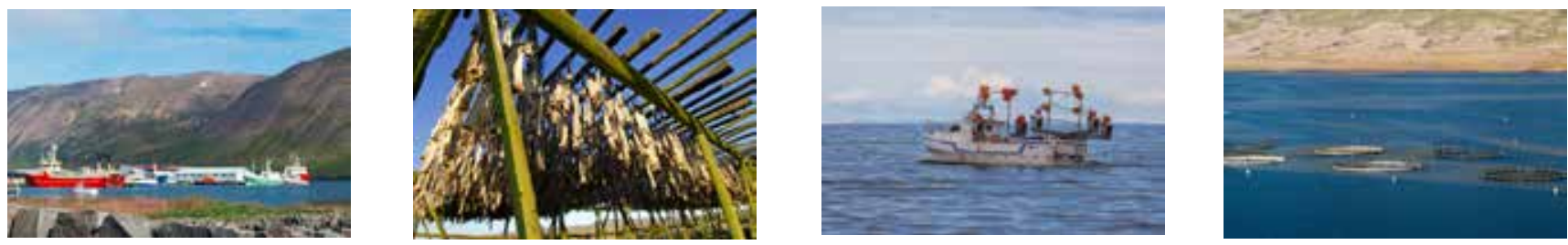

management measures that protect habitat and reproduction capabilities in the ecosystem have always been in place along with the ITQ system.

putting the fisheries on a more sustainable footing. As the focus of ITQs is typically limited to a subset of commercially exploited fish species, their ability to conserve biodiversity in the broader context is constrained by the scope of their application. When it comes to limiting the overall effects of fishing on biodiversity, other measures in addition to TACs for different species are needed. ${ }^{6}$ Thus, traditional

6. For a discussion on similar issues in New Zealand, see Mace, Sullivan and Cryer (2014) and for a general discussion of how incentive based measures may be applied to help conserve biodiversity see Pascoe et al. (2010) and Innes et al. (2015).

Biodiversity protection needs additional safeguards

Although the reform was mainly driven by economic 


\section{References}

Arnason, R. (2005), "Property rights in fisheries: Iceland's experience with ITQs", Reviews in Fish Biology and Fisheries, 15(3): 243-264. Asche, F. et al. (2014), "Development in fleet fishing capacity in rights based fisheries”, Marine Policy, Vol 44 (February): 166-171. Ásgeirsson, G. (2012), "Kvótakerfið í fiskveiðum. Tilurð pess og áhrif á byggð og samfélag”, [The quota system in fisheries. How it came about and its effect on regional development and societies], unpublished BA-thesis, University of Iceland, http://skemman. is/en/stream/get/1946/11547/28678/1/Gu\%C3\%BOmundur_\%C3\%81sgeirs.pdf.

Financial Management Authority [Fjársýsla ríkisins] (2016), Rikisreikningur 2015 [Public Accounts 2015], Financial Management Authority, www.fjs.is/utgefid-efni/rikisreikningur.

Haraldsson, G. (2008), "Impact of the Icelandic ITQ system on outsiders", Aquatic Living Resources, Vol. 21, pp. 239-245.

Innes, J. et al. (2015), "Mitigating undesirable impacts in the marine environment: a review of market-based management measures”, Frontiers in Marine Science, Vol. 2. Article 76, http://journal.frontiersin.org/article/10.3389/fmars.2015.00076/full.

Karlsson, V. and H. Johannesson (2016), Skýrsla um ráðstöfun aflamangs sem dregið er frá heildarafla og áhrif pess á byggðafestu [Report on the TAC and its effects on sustainability], Rannsóknarmiðstöð Háskólans á Akureyri, University of Akureyri.

Mace, P.M., et al. (2014), “The evolution of New Zealand's fisheries science and management systems under ITQs”, ICES Journal of Marine Science, 71(2): 204-215.

Matthiasson, T. (2008), "Rent collection, rent distribution, and cost recovery: an analysis of Iceland's ITQ catch fee experiment”, Marine Resource Economics 23, no. 1 (2008): 105-117.

MENR (2014), The Fourth National Report to the Convention on Biological Diversity, Ministry for the Environment and Natural Resources, Reykjavík, www.cbd.int/doc/world/is/is-nr-04-en.pdf.

National Economic Institute [pjóðhagsstofnun] (1999), Próun sjávarútvegs, kuótakerfið, auðlindagjald og almenn hagstjórn [Development of the fisheries quota system, resource tax and economic management], National Economic Institute, Reykjavík, www. atvinnuvegaraduneyti.is/media/2011/Thjodhagstofnunarskyrsla1999.pdf.

OECD (2017), The Political Economy of Biodiversity Policy Reform, OECD Publishing, Paris, http://dx.doi.org/10.1787/9789264269545-en. OECD (2012), Rebuilding Fisheries: The Way Forward, OECD Publishing, Paris, http://dx.doi.org/10.1787/9789264176935-en. OECD (n.d.), "Country note on national fisheries management systems - Iceland”, OECD, Paris, www.oecd.org/iceland/34429527.pdf. Pascoe, S., et al. (2010), "Use of incentive-based management systems to limit bycatch and discarding”, International Review of Environmental and Resource Economics, 4(2): 123-161, http://dx.doi.org/10.1561/101.00000032.

Runolfsson, B. Th. (1997), "Regional impact of the individual transferable quotas in Iceland”, In Jones, L. and M. Walker (eds), Fish or Cut Bait! The Case for Individual Transferable Quotas in the Salmon Fishery of British Columbia, Fraser Institute, Vancouver, BC.

Schrank, W.E. (2003), "Introducing fisheries subsidies", FAO Fisheries Technical Paper 437, Food and Agriculture Organization of the United Nations (FAO), Rome, www.fao.org/3/a-y4647e.pdf.

Statistics Iceland (2016), "Rekstraryfirlit fiskveiða 1997-2015" [Operating Fisheries 1997-2015], http://px.hagstofa.is/pxis/ pxweb/is/Atvinnuvegir/Atvinnuvegir_sjavarutvegur_afkomasja/SJA08101.px, (accessed 16 August 2016).

Statistics Iceland (2014), “Rekstraryfirlit sjávarútvegs 2008-14” [Operating Fisheries 2008-14], database, http://px.hagstofa.is/ pxis/pxweb/is/Atvinnuvegir/Atvinnuvegir_sjavarutvegur_afkomasja/SJA08109.px/table/tableViewLayout1/?rxid=38f8b711203c-4c5a-85e9-4d08032dc1ce (accessed 30 August 2016).

University Centre of the Westfjords (2010), Úttekt á framgangi og áhrifum strandveiðanna sumarið 2009 [Stock of the progress and effects of coastal fishing in summer 2009], University Centre of the Westfjords, Ísafjörður. 


\section{Photo Credits}

Front \& back cover: Commercial fishing boat in Icelandic waters, snowy mountains in background ๑ Johann Ragnarsson / shutterstock.com Inside cover: Waves at coast of Hrisey in Iceland during a winter storm $\odot$ Gestur Gislason / shutterstock.com Page 1: Commercial fishing vessel, Westfjords, Iceland ๑ Tabor Chichakly / shutterstock.com Page 1: Fresh catch cod on the boat, ocean and sea fishing, Iceland $\odot$ Daria Medvedeva / shutterstock.com Page 1: City seascape of Reykjavik, Iceland with mountains in the background $\odot$ Polarpx / shutterstock.com Page 1: school of jack fish ๑ unterwegs / shutterstock.com

Page 1: White lighthouse at the port of Akranes, Iceland ๑ kb-photodesign / shutterstock.com Page 2 \& 3: Small fishing Harbor with fishing ships, Hofn town, Southeast Iceland ๑ Palis Michalis / shutterstock.com Page 5: Icelandic fishermen process and clean fish catch in Reykjavik, Iceland ๑ Pavel Svoboda Photography / shutterstock.com Page 7: Dramatic clouds over Sudureyri fish farm in Sugandafjordur Westfjords Iceland $\odot$ Tabor Chichakly / shutterstock.com Page 8: Atlantic cod (Gadus morhua) Marine fish ๑ Vladimir Wrangel / shutterstock.com Page 9: Fish market @ Milena Mladenova / shutterstock.com Page 10: A puffin holding fish in his mouth, on a cliff, in southeastern Iceland ๑ RnDmS / shutterstock.com Page 11: Fishing boats in the port of Siglufjordur, a small fishing town, northern coast of Iceland ๑ Naeblys / shutterstock.com

Page 11: Traditional open-air fish drying to make Hardfiskur, Iceland @ Frantisek Staud / shutterstock.com Page 11: Commercial fishing boat mackerel fishing, south-west coast of Iceland $\odot$ Johann Ragnarsson / shutterstock.com Page 11: Iceland (Summer), fish farming in the Faskruosfjorour fjord @ Matteo Provendola / shutterstock.com Page 11: Iceland 3405 Fishing boat $\odot$ Reinhard Tiburzy / shutterstock.com Page 12: Lines and fenders @ fotoknips / shutterstock.com Page 13: Faxi Falls with fish ladder for salmon, Iceland ๑ MicheleB / shutterstock.com

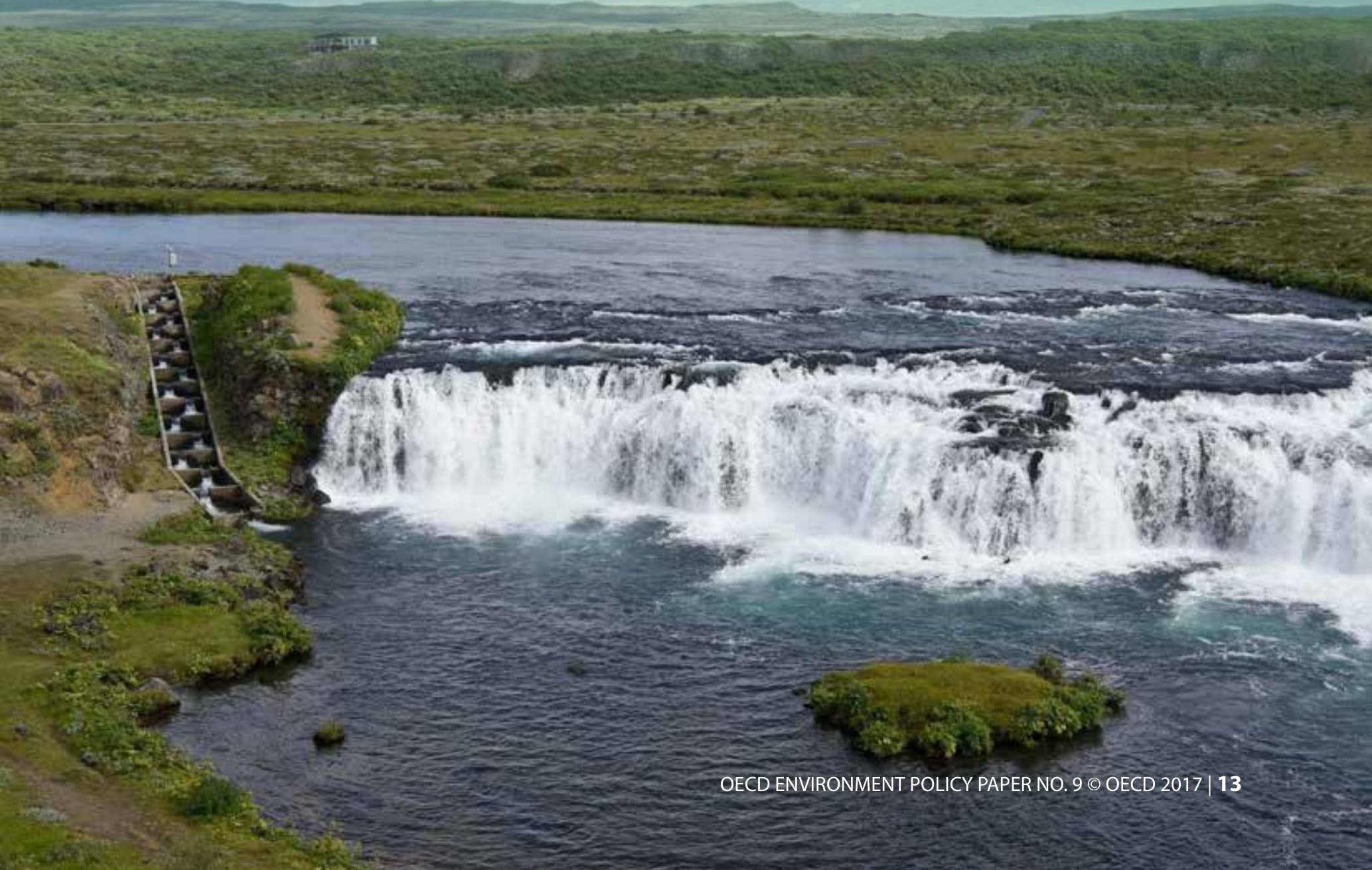




\section{Sustaining Iceland's fisheries through tradeable quotas}

This Policy Paper analyses the reform undertaken by Iceland to avert a looming crisis and restore fish stocks to sustainable levels. The paper outlines the process involved in designing and implementing this reform. It also reflects on the challenges encountered and the environmental, economic and social impacts of the reform. It concludes by discussing some wider lessons learned for other governments seeking to tackle similar environmental problems. This country study draws on the 2017 OECD report The Political Economy of Biodiversity Policy Reform.

\section{The OECD Environment Policy Paper series}

Designed for a wide readership, the OECD Environment Policy Papers distil lessons from many of today's environment-related policy issues, drawing on a wide range of OECD work. In the form of country case studies or thematic reviews across countries, the papers highlight practical implementation experience. They are available in either English or French, with a summary in other languages when possible.

For further reading on the political economy of biodiversity-related reform, see the following report on which this Policy Paper is based:

OECD (2017), The Political Economy of Biodiversity Policy Reform, OECD Publishing, Paris, www.oecd.org/environment/the-political-economy-of-effective-biodiversity-policyreform-9789264269545-en.htm.

\section{Visit our websites}

www.oecd.org/environment/resources/biodiversity.htm www.oecd.org/environment/resources/mainstream-biodiversity

\section{Join the discussions}

@OECD_ENV and \#MainstreamBiodiversity

Contact: katia.karousakis@oecd.org 